To cite: Al Ofuani 'Protecting adolescent girls with intellectual disabilities from involuntary sterilisation in Nigeria: Lessons from the Convention on the Rights of Persons with Disabilities ' (2017) 17 African Human Rights Law Journal 550-570

http://dx.doi.org/10.17159/1996-2096/2017/v17n2a9

\title{
Protecting adolescent girls with intellectual disabilities from involuntary sterilisation in Nigeria: Lessons from the Convention on the Rights of Persons with Disabilities
}

\author{
Anwuli Irene Ofuani* \\ Lecturer, University of Benin, Nigeria; Doctoral Candidate, Centre for Human \\ Rights, University of Pretoria, South Africa
}

\begin{abstract}
Summary
Adolescent girls with intellectual disabilities are highly susceptible to involuntary sterilisation in Nigeria. Existing Nigerian laws contain no provisions expressly prohibiting involuntary sterilisation and the provisions that could be indirectly applied are inadequate. Accordingly, this article seeks to draw lessons from the provisions of the Convention on the Rights of Persons with Disabilities that are pertinent to protecting adolescent girls with intellectual disabilities from involuntary sterilisation in Nigeria. In doing this, it examines four provisions of the CRPD, namely, the rights to respect for home and the family (article 23); health (article 25); equality and non-discrimination (article 5); and equal recognition before the law (article 12). The right to retain fertility in article 23 can unequivocally be construed as prohibiting involuntary sterilisation of persons with disabilities. In Nigeria, the recognition of people's right to consent to medical procedures, including sterilisation, determines whether or not they are allowed to consent to such procedures. Accordingly, a lack of informed consent results in third parties making decisions about sterilisation without consulting those about whom the decisions are made. Also, involuntary sterilisation is an issue of inequality and discrimination and, thus, the right to equality and non-discrimination is very important in protecting adolescent girls with intellectual disabilities from involuntary sterilisation. The article contends that the CRPD provides an avenue for challenging the discrimination and inequality that sterilisation presents for adolescent girls with intellectual disabilities in Nigeria, and makes recommendations based on the provisions of the CRPD.
\end{abstract}

* LLB (Benin) LLM (Cape Town); wulis4ever@yahoo.com 
Key words: adolescent; Convention on the Rights of Persons with Disabilities; girls; intellectual disabilities; sterilisation

\section{Introduction}

Sterilisation is a permanent form of preventing pregnancy and involves situations where girls and women are sterilised without their knowledge, or are coerced, deceived or misinformed to undergo sterilisation. ${ }^{1}$ Involuntary sterilisation, therefore, regulates a person's fertility, with the intent to permanently end the person's capability to reproduce, shorn of his or her approval and/or knowledge. ${ }^{2}$ It is an 'act of violence and discrimination' that infringes on the right of adolescent girls with intellectual disabilities to the integrity of their bodies. ${ }^{3}$ It has far-reaching implications on their rights to equality, dignity and autonomy as well as their rights to sexual and reproductive health. ${ }^{4}$ It has generally been justified on the grounds of eugenics; menstruation management; the prevention of sexual abuse; the prevention of unplanned pregnancies; and the financial burden on family members; all of which are unfounded. ${ }^{5}$ The involuntary sterilisation of women and girls, including those with intellectual disabilities, has in the last decade been a topical issue and a subject of remarks from treaty-monitoring bodies and UN Special Rapporteurs. For instance, the African Commission on Human and Peoples' Rights

1 American Congress of Obstetricians and Gynaecologists 'Sterilization for women and men' https://www.acog.org/ /media/For\%20Patients/faq011.pdf (accessed 12 November 2017); 'What every woman should know about female sterilization' https://www.healthline.com/health/birth-control-female-sterilization\# about1 (accessed 12 November 2017); K Krase 'History of forced sterilization and current US abuses' http://www.ourbodiesourselves.org/health-info/forced-sterili zation/ (accessed 12 November 2017); C Frohmader 'Briefing paper: Sterilisation of women and girls with disabilities: An update on the issue in Australia' http:// wwda.org.au/wpcontent/uploads/2013/12/Sterilisation_of_Women_and_Girls_ with_Disabilities_UpdateDec2012.pdf (accessed 8 October 2016).

2 Open Society Foundations 'Against her will: Forced and coerced sterilisation of women worldwide' 2 http://www.opensocietyfoundations.org/sites/default/files/ against-her-will-20111003.pdf (accessed 8 October 2016); Advocates for Human Rights 'Forced/coerced sterilisation' http://www.stopvaw.org/forced_coerced_ sterilization (accessed 08 October 2016); Forced sterilisation http://www2. webster.edu/ woolflm/forcedsterilization.html (accessed 8 October 2016); R Coomaraswamy 'Violence against women (addendum): Policies and practices that impact women's reproductive rights and contribute to, cause or constitute violence against women' Report of the Special Rapporteur on Violence against Women, Its Causes and Consequences E/CN.4/1999/68/Add. para 51, http:// www.unhchr.ch/Huridocda/Huridoca.nsf/0/4cad275a8b5509ed8025673800503f 9d?Opendocument (accessed 8 October 2016).

3 Coomaraswamy (n 2 above) para 51; C Spicer 'Sterilisation of women and girls with disabilities - A literature review' http://www.wwda.org.au/issues/sterilise/ sterilise1995/steril/ (accessed 8 October 2016).

4 C Stimpson 'Involuntary sterilisation of people with disabilities - A response to the senate report' (2013) 22 Human Rights Defender 14.

$5 \mathrm{OHCHR}$ et al 'Eliminating forced, coercive and otherwise involuntary sterilisation An interagency statement' http://www.who.int/reproductivehealth/publications/ gender_rights/eliminating-forced-sterilization/en/ (accessed 8 October 2016). 
(African Commission) declared, among others, that it violates the right to 'equality and non-discrimination, dignity, liberty and security of the person'. ${ }^{6}$ Similarly, the Committee on the Elimination of All Forms of Discrimination Against Women (CEDAW Committee) confirmed that it is a violation of the rights to informed consent, dignity and integrity. ${ }^{7}$ The CEDAW Committee also stated that the sterilisation of girls, including girls with disabilities, against their knowledge, should be proscribed. ${ }^{8}$ The United Nations (UN) Special Rapporteur on Violence Against Women and the Committee on the Rights of the Child (CRC Committee) have also acknowledged that that involuntary sterilisation of girls with disabilities violates their bodily integrity. ${ }^{9}$ In the same way, the UN Special Rapporteur on Torture has emphasised that involuntary sterilisation constitutes torture and cruel or inhuman treatment. ${ }^{10}$

Adolescent girls with intellectual disabilities in Nigeria are highly susceptible to sterilisation, which in many cases is carried out without their knowledge or without their proper understanding of what it entails. In addition, anecdotal evidence reveals that in Nigeria sterilisation is more likely to be sought for girls with intellectual disabilities than their male counterparts, their counterparts with other forms of disabilities or their non-disabled counterparts. Thus, it is not merely a gendered issue, but also an issue of discrimination and unequal treatment, reinforced by legal, traditional and social values. Hence, it is imperative that adolescent girls with intellectual disabilities are protected from involuntary sterilisation as it infringes on their rights to equality and freedom from discrimination. The Convention on the Rights of Persons with Disabilities (CRPD) ${ }^{11}$ provides an avenue for challenging the discrimination and inequality that sterilisation presents for adolescent girls with intellectual disabilities. Accordingly, the article aims at drawing lessons from the provisions of the CRPD for Nigeria in terms of protecting adolescent girls with intellectual disabilities from involuntary sterilisation. Part 1 of the article is an

6 African Commission on Human and Peoples' Rights Resolution 260 on Involuntary Sterilisation and the Protection of Human Rights in Access to HIV Services http:// www.achpr.org/sessions (accessed 8 October 2016).

7 CEDAW Committee General Recommendation 24: Article 12 of the Convention (women and health) A/54/38/Rev.1, ch 1 para 22.

8 CEDAW Committee Concluding Observations of the Committee on the Elimination of Discrimination against Women: Australia' CEDAW 46th session, 12-30 July 2010 CEDAW/C/AUS/CO/7.

9 CRC Committee 'Article 19: The right of the child to freedom from all forms of violence' General Comment 13 (2011) CRC/C/GC/13 paras 16 \& 21; R Manjoo 'Special Rapporteur on Violence against Women, Its Causes and Consequences 'Report of the Special Rapporteur on Violence against Women, Its Causes and Consequences (2012) UN Doc A/67/227 para 28; M Nowak 'Promotion and protection of all human rights, civil, political, economic, social and cultural rights, including the right to development' Report of the Special Rapporteur on Torture and Other Cruel, Inhuman or Degrading Treatment or Punishment (2008) A/HRC/ $7 / 3$ paras $38 \& 39$

10 Nowak (n 9 above) paras $38 \& 39$.

11 Convention on the Rights of Persons with Disabilities (CRPD) (2006) 46 ILM 443. 
introduction; part 2 discusses the sterilisation of adolescent girls with intellectual disabilities in Nigeria in the context of equality and nondiscrimination. Part 3 discusses the articles of the CRPD pertinent to protecting adolescent girls with intellectual disabilities from involuntary sterilisation. Part 4 discusses the challenges inherent in protecting adolescent girls with intellectual disabilities from involuntary sterilisation along the lines of the discussed provisions of the CRPD. Part 5 makes recommendations with regard to the implementation of the provisions of the CRPD discussed in part 3. Part 6 concludes the article.

\section{Involuntary sterilisation of adolescent girls with intellectual disabilities in Nigeria as inequality and discrimination}

The Nigerian Constitution provides for 'equality of rights, obligations and opportunities before the law' for every Nigerian citizen. ${ }^{12}$ Similarly, the African Charter on Human and Peoples' Rights (Ratification and Enforcement) Act 1983 provides for equality and 'equal protection of the law'. The Nigerians with Disability Act 1993 (NWDA), the only federal legislation specifically dealing with disability rights in Nigeria, also provides for equal rights, obligations and prospects for persons with disabilities. ${ }^{13}$ These provisions guarantee equal treatment to all Nigerians, including adolescent girls with intellectual disabilities on an equal basis as other adolescents. However, the right to equality contained in the Constitution is enshrined within the fundamental objectives and directive principles

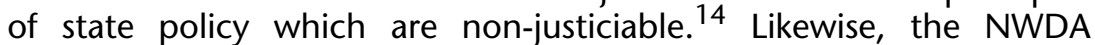
contains no provisions prohibiting involuntary sterilisation and protecting the rights of girls to retain their fertility. Nonetheless, section 42 of the Constitution, which is a fundamental human right, provides for freedom from discrimination on grounds including circumstance of birth for all Nigerians. ${ }^{15}$ Thus, the involuntary sterilisation of adolescent girls with intellectual disabilities on account of their disability infringes on section 42.

In spite of these provisions, evidence reveals that adolescent girls with intellectual disabilities are subjected to involuntary sterilisation at the instance of family members. Although there is a lack of data indicating the incidence of involuntary sterilisation of girls with

12 Constitution of the Federal Republic of Nigeria of 1999 Cap C.34, LFN 2004, sec $17(2)(a)$.

13 The Nigerians with Disability Act of 1993 (NWDA), secs $1 \&$ 2(a). The NWDA was originally a decree but by virtue of sec 315 of the 1999 Constitution, the NWDA, like other existing Federal Decrees, became an Act. It is yet to be repealed by any law and is still in force.

14 Ch 2 Constitution of the Federal Republic of Nigeria ( $\mathrm{n} 12$ above).

15 Sec 42(3) Nigerian Constitution. 
intellectual disabilities, it can be deduced that it occurs in Nigeria. ${ }^{16}$ For instance, Animashaun discussed the criteria and indications for sterilisation of girls with disabilities as seen from past clinical practice in Nigeria. According to him, sterilisation can be carried out on request by parents or guardians; if there is a severe handicap so incapacitating as to impede effective parenthood; if there is a high risk of hereditary conditions such as Down syndrome; as well as the presence of a low level of intelligence or psychiatric disorders. ${ }^{17}$ Similarly, in a 2015 report, it was stated that girls with intellectual disabilities were involuntarily sterilised to prevent them from falling pregnant, especially in situations of sexual abuse. More so, in a recent empirical research involving 224 respondents, 87 (38,8 per cent) of respondents acknowledged that they had heard of or knew of instances where adolescent girls with intellectual disabilities had been sterilised. ${ }^{18}$ The prevention of pregnancy, especially in situations where the girl has fallen pregnant a few times, and financial incapability, were the reasons most selected by the respondents. ${ }^{19}$ In fact, 81 (36,1 per cent) respondents believed that pregnancy, especially where girls with intellectual disabilities have fallen pregnant a few times, was enough reason to sterilise the girls. Likewise, 52 (23,2 per cent) respondents believed that financial incapability was enough reason to sterilise the girls. ${ }^{20}$ The discrimination inherent in these responses is that sterilisation usually is not carried out on adolescent girls without disabilities to prevent pregnancy or because of financial incapability. ${ }^{21}$

The gendered aspect to sterilisation in Nigeria is underlined by the fact that the Penal Code, which is applicable in the northern part of Nigeria, penalises emasculation, which is categorised as grievous hurt, with a prison term of up to seven years. ${ }^{22}$ Emasculation, in this context, means rendering a man incapable of reproduction There is no such corresponding provision for women or girls. Therefore, it can be inferred that the provision protects males from sterilisation, at least in northern Nigeria, but not females. Undoubtedly, sterilisation places adolescent girls with intellectual disabilities in a position of inequality and discrimination contravening the provisions of the aforementioned

16 A Animashaun 'Indications for the sterilisation of the handicapped adolescent' (1978) 8 Nigerian Medical Journal 253-254; D Olubukola 'Intellectually retarded education in Nigeria: Past, present, and future' (2007) 22 Essays in Education 75.

17 Animashaun (n 16 above) 254.

18 The research is the empirical component of the author's ongoing PhD research. Ethical clearance was obtained from the Ethics Committee of the Faculty of Law, University of Pretoria. The research involved the administration of questionnaires to the parents of adolescent girls with intellectual disabilities aged 13 to 18 years in 17 schools for children with intellectual disabilities and 144 professionals, including teachers and doctors working with these girls in Anambra, Edo, Ekiti, Imo, Lagos and Rivers State in Nigeria.

19 As above.

20 As above.

21 As above.

22 Cap P3, LFN, 2010, secs $244 \& 247$. 
Nigerian laws. Nonetheless, law reform still is required to ensure that the aforementioned laws adequately protect the rights of adolescent girls with intellectual disabilities. The inclusion of disability as a ground for discrimination in the Nigerian Constitution and the NWDA as well as the inclusion of a provision on reasonable accommodation in line with the CRPD is necessary.

\section{Convention on the Rights of Persons with Disabilities and the protection of adolescent girls with intellectual disabilities from involuntary sterilisation}

Nigeria has signed and ratified the CRPD and its Optional Protocol as well as other internal human rights laws, thus evincing a clear intention to be bound by the duties imposed by international law. ${ }^{23}$ Nigeria operates a dualistic system that requires the CRPD to be incorporated into national law before taking effect. However, no law has been enacted at the federal level to reflect the provisions of the CRPD as the NWDA was enacted before the CRPD came into force. Notwithstanding this limitation, some states in Nigeria, such as Lagos, Rivers and Plateau states, have enacted disability laws given that disability is within the legislative competence of states. Yet, none of the state laws contains provisions prohibiting involuntary sterilisation. At best, they contain provisions prohibiting discrimination, harmful practices and cruel and inhuman treatment which implicitly can be relied on to prevent sterilisation. ${ }^{24}$ Recent federal disability bills also contain no provisions prohibiting involuntary sterilisation or recognising the right to equality before the law and legal capacity but only contain provisions on discrimination and harmful practices. ${ }^{25}$ Consequently, lessons could be drawn from the CRPD in the subsequent enactment or amendments of laws in Nigeria.

The CRPD contains many provisions that could be construed as prohibiting involuntary sterilisation and protecting girls with intellectual disabilities from involuntary sterilisation. However, this section only examines four rights in the CRPD which directly impact on the protection of girls with intellectual disabilities from involuntary

23 Nigeria signed the CRPD on 30 March 2007 and ratified it on 24 September 2016. See The United Nations Treaty Collection Chapter IV 15 (status as at 6 July 2016) https://treaties.un.org/ (accessed 6 July 2016).

24 Lagos State Special People's Law of 2010, secs 26, 27 \& 31 https://www.lagos houseofassembly.gov.ng/download/special-peoples-law-vol-5/ (accessed 6 July 2016).

25 Discrimination Against Persons with Disabilities (Prohibition) Bill 2015, sec 1, http://placng.org/wp/wp-content/uploads/2016/07/SB22.pdf (accessed 6 July 2016); Nigerians with Disabilities Bill Act 2016, secs 1 \& 2 http://placng.org/wp/ wp-content/uploads/2016/07/SB22.pdf (accessed 6 July 2016); Kwara State People with Disabilities Bill 2016, secs 11 \& 12 http://www.kwha.gov.ng/KWHA/ Pages/_ peoplewithdisabilitiesbill2016 (accessed 6 July 2016). 
sterilisation, specifically in relation to equality and non-discrimination for the purpose of drawing lessons from them. These rights are the rights to respect for home and the family; equality and nondiscrimination; equal recognition before the law; and health. These rights are interconnected as involuntary sterilisation usually occurs without the consent of the person sterilised and usually emanates from a position of inequality, discrimination and incapacity.

\subsection{Article 23 - The right to respect for home and family}

Article 23 of the CRPD contains a number of rights guaranteeing respect for the home and family of persons with disabilities. Article 23(1)(c) unequivocally protects adolescent girls with intellectual disabilities from involuntary sterilisation. ${ }^{26}$ It provides that persons with disabilities, including children (which include adolescents), have the right 'to retain their fertility on an equal basis with others' ${ }^{24}$ Thus, the Committee on the Rights of Persons with Disabilities (CRPD Committee) observed that involuntary sterilisation contravenes the right to retain fertility as provided for in article 23 of the CRPD. ${ }^{28}$ Similarly, the Committee acknowledged that laws, policies and practices that allow involuntary sterilisation violate the provisions of article 23 of the CRPD and should be amended or repealed. ${ }^{29}$

The provisions of article 23 are generally non-discriminatory requirements that ensure that persons with disabilities are subject to the same standards as other members of society. ${ }^{30}$ Consequently, it enables adolescent girls with intellectual disabilities to be accorded the right to retain their fertility and be free from involuntary sterilisation on the same basis as other adolescents. It enjoins state parties to ensure that 'effective and appropriate measures' are adopted at the national level, so as to eliminate discrimination against persons with disabilities in terms of their rights to retain their fertility on the same basis as others. ${ }^{31}$ Such measures include the enactment, amendment or repealing of laws; sensitisation and awareness raising; as well as access to age-appropriate information and contraceptive services and support. ${ }^{32}$ Yet, there are no provisions in Nigerian law

26 Art (1)(c) CRPD.

27 Art 23(1)(c) Convention on the Rights of Persons with Disabilities (n 11 above).

28 CRPD Committee 'Concluding Observations on the initial report of Hungary' UN Doc CRPD/C/HUN/CO/1, para 38; CRPD 'Concluding Observations on the initial report of China' UN Doc CRPD/C/CHN/CO/1, para 34; CRPD Committee 'Concluding Observations on the initial report of Peru' UN Doc CRPD/C/PER/CO/ 1 , para 35.

29 Concluding Observations on the initial report of China (n 28 above) para 34.

30 'Letter dated 2005/10/07 from the Chairman to all Members of the Committee' A/AC.265/2006/1 para 85 https://daccess-ods.un.org/TMP/9879887.7000 808.html (accessed 8 October 2016); V Della Fina 'Article 23 [Respect for Home and the Family]' in V Della Fina et al (eds) The United Nations Convention on the Rights of Persons with Disabilities: A Commentary (2017) 417428.

31 Art 23(1) CRPD; Della Fina (n 30 above) 434-435.

32 Della Fina (n 30 above) 434. 
guaranteeing the right to retain fertility for women and girls. As such, incorporating provisions guaranteeing the right to retain fertility into Nigerian law could prove to be a veritable mechanism in protecting adolescent girls with intellectual disabilities from involuntary sterilisation.

\subsection{Article 25 - Right to health}

Sterilisation has adverse health effects as it impacts negatively on the mental, physical and reproductive health of adolescent girls with intellectual disabilities. ${ }^{33}$ Article 25 of the CRPD recognises that persons with disabilities are entitled to the utmost standard of health shorn of discrimination on the basis of their disability. ${ }^{34}$ By contrast, the NWDA merely provides that 'free medical and health services' be made available to persons with disabilities and shall be provided in all public health institutions. ${ }^{35}$

The nature of the consent given by a person determines whether or not the sterilisation is involuntary. If consent to sterilisation is forced or coerced, it amounts to involuntary sterilisation. ${ }^{36}$ In view of this, the CRPD requires that persons with disabilities be accorded the opportunity to provide free and informed consent in healthcare. ${ }^{37}$ It requires state parties to prohibit discrimination in healthcare on the basis of disability by including persons with disabilities in the process of making decisions concerning their treatment through informed consent. $^{38}$ Hence, any non-consensual treatment, including involuntary sterilisation, would contravene the provisions of article 25 . As a result, the CRPD Committee stated that laws allowing involuntary treatment based on the consent of third parties such as family members or guardians should be repealed. 39 This reinforces the standards contained in article 12 pertaining to equality before the law and the right to legal capacity. ${ }^{40}$

33 C Frohmader 'Dehumanised: The forced sterilisation of women and girls with disabilities in Australia' Human Rights Watch 'Sterilization of women and girls with disabilities' https://www.hrw.org/news/2011/11/10/sterilization-women-and-girlsdisabilities (accessed 8 October 2016); WWDA Submission to the Senate Inquiry into the involuntary or coerced sterilisation of people with disabilities in Australia (2013) 11 http://wwda.org.au/wp-content/uploads/2013/12/WWDA_Sterilisation _Sub_Summary_and_Recs.pdf (accessed 8 October 2016). Art 25 CRPD.

35 Sec 4(1)(a) The Nigerians with Disability Act (n 13 above).

36 C Frohmader Moving forward and gaining ground: The sterilisation of women and girls with disabilities in Australia (2012) 5. See also Open Society Foundations (n 2 above) 4; A d'Espallier 'Cutting the ties: Sterilisation of persons with disabilities new perspectives after the introduction of the CRPD' 3 http://www.jus.uio.no/ english/research/news-and-events/events/conferences/2014/wccl-mdc/wccl/pap ers/ws7/w7-despallier\%20.pdf (accessed 8 October 2016).

37 Art 25(d) CRPD.

38 IR Pavone 'Article 25 [Health]' in in Della Fina et al (n 30 above) 471478.

39 Concluding Observations on the initial report of China (n 28 above) para 23.

40 Pavone (n 38 above) 478. 
Nonetheless, persons with intellectual disabilities by comparison often are considered incapable of free and informed consent in healthcare. This gives rise to their unequal treatment and discrimination against them. ${ }^{41}$ In Nigeria, medical practice is evolving to allow adolescents to consent independently to being given contraception as long as they can understand the nature, risks and benefits of the contraceptives. ${ }^{42}$ However, for adolescent girls with intellectual disabilities consent often emanates from their parents, guardians or, in some cases, healthcare professionals. Substituted decision making ${ }^{43}$ generally is used to justify involuntary contraception and sterilisation on the paternalistic that ground they are incapable of making decisions for themselves and, thus, should be protected. ${ }^{44}$ Therefore, contrary to the human rights standards in the CRPD, they are subjected to a practice that their non-disabled counterparts are not subjected to, thereby placing them in a position of inequality and being discriminated against.

\subsection{Article 5 - Right to equality and non-discrimination}

The right to equality and non-discrimination is fundamental to the human rights of persons with disabilities because most issues affecting persons with disabilities, including involuntary sterilisation, may be framed within the context of equality and non-discrimination. ${ }^{45}$ It underpins the notion that all persons are equal irrespective of their station in life and are entitled to the same set of rights. ${ }^{46}$

Article 5 provides for the right to equality and non-discrimination. It recognises that all persons are 'equal before and under the law' and are 'entitled to equal protection and benefit of the law' without discrimination. ${ }^{47}$ It prohibits discrimination on the basis of disability. ${ }^{48}$

41 D'Espallier (n 36 above) 3.

42 n 18 above.

43 Substituted decision making involves a third party making a decision for a person without any input or without consulting the person for whom the decision is being made. See Office of the Public Advocate (OPA) South Australia 'Making decisions for others - Substitute decision making' http://www.opa.sa.gov.au/ making_decisions_for_others/substitute_decision_making (accessed 8 October 2016).

44 Mental Disability Advocacy Centre and the World Network of Users and Survivors of Psychiatry 'Submission to the UN Special Rapporteur on Torture on his upcoming thematic paper on torture in the context of healthcare' para $22 \mathrm{http}: / /$ www.wnusp.net/documents/2012/2012_11_06_TorturelnHealthcare_submission. doc (accessed 8 October 2016).

45 J Kumpuvuori \& M Scheinin 'Treating the different ones differently - A vehicle for equality for persons with disabilities? Implications of article 5 of the Convention on the Rights of Persons with Disabilities' in J Kumpuvuori \& M Scheinin (eds) United Nations Convention on the Rights of Persons with Disabilities Multidisciplinary perspectives (2010) 54.

46 R Cera 'Article 5 [Equality and Non-Discrimination]' in Della Fina et al (n 30 above) 158.

47 Art 5(1) CRPD.

48 Arts 5(2) \& 5(3) CRPD. 
Discrimination on the basis of disability is defined in the CRPD as follows: ${ }^{49}$

Discrimination on the basis of disability means any distinction, exclusion or restriction on the basis of disability which has the purpose or effect of impairing or nullifying the recognition, enjoyment or exercise, on an equal basis with others, of all human rights and fundamental freedoms in the political, economic, social, cultural, civil or any other field. It includes all forms of discrimination, including denial of reasonable accommodation.

Article 5 also urges state parties to ensure that persons with disabilities are provided reasonable accommodation to promote equality and eliminate discrimination against them. ${ }^{50}$ Reasonable accommodation is defined as

necessary and appropriate modification and adjustments not imposing a disproportionate or undue burden, where needed in a particular case, to ensure to persons with disabilities the enjoyment or exercise on an equal basis with others of all human rights and fundamental freedoms. ${ }^{51}$

Sterilisation infringes on the right to equality and discrimination contained in article 5 since sterilisation in most cases occurs on the basis of their disability and results in unequal treatment. Article 5, therefore, is useful in addressing the discriminatory beliefs that give rise to the sterilisation of girls with intellectual disabilities in Nigeria. It goes beyond the provisions of section 42 of the Nigerian Constitution by providing for reasonable accommodation. As Lord observes, the CRPD's right to provide reasonable accommodation applies to a wide range of actors, including the state and health care providers, requiring them to adjust policies and practices that allow the exclusion and lack of participation of persons with disabilities. ${ }^{52}$ It requires the enactment and revision of laws and policies as well as concrete comprehensive action on the part of the government to prevent or stop discrimination by government authorities, the judiciary, institutions or private individuals. ${ }^{53}$

\subsection{Article 12 - Right to equal recognition before the law}

Article 12, which is at the core of the CRPD, reaffirms the ubiquitous nature of equality. It reaffirms the rights of persons with disabilities to respect as 'persons before the law'. 54 It acknowledges their 'right to legal capacity on an equal basis with others in all aspects of life' and to be supported in realising their legal capacity. ${ }^{55}$ It also requires that

\footnotetext{
49 Art 2 CRPD.

50 Arts 5(2) \& 5(3) CRPD.

51 Art 2 CRPD.

52 JE Lord \& R Brown 'The role of reasonable accommodation in securing substantive equality for persons with disabilities: The UN Convention on the Rights of Persons with Disabilities' 5 https://ssrn.com/abstract=1618903 (accessed 12 November 2016).

53 Cera (n 46 above) 166.

54 Art 12(1) CRPD.

55 Arts 12(2) \& (3) CRPD.
} 
such support be in line with the 'rights, will and preferences of the person' ${ }^{56}$ As Frohmader points out, the significance of article 12 is that an individual's right to decision making cannot be substituted by that of a third party, and the individual has the right to make his or her own choices. ${ }^{57}$

The CRPD Committee, in interpreting article 12, states that 'equality before the law' is an innate human rights tenet which is crucial to the implementation of other human rights. ${ }^{58}$ In other words, the right in article 12 to equal recognition before the law with its attendant right to legal capacity and support in the exercise of legal capacity is vital to the realisation of other rights in the CRPD. Therefore, article 12 is necessary for the implementation of article 23 and the protection of adolescent girls with intellectual disabilities from being sterilised involuntarily. For the Committee, equality before the law indicates that legal capacity is universal and upholds the full legal capacity of persons with disabilities, which hitherto had been denied. ${ }^{59}$ However, the CRPD Committee observed that the deprivation of the legal capacity of persons with disabilities has also resulted in the deprivation of their fundamental rights, including their reproductive rights. ${ }^{60}$ The CRPD Committee also construed legal capacity as the 'capacity to be both a holder of rights and an actor under the law'. Capacity to hold rights ensures that a person's rights are safeguarded by the legal system while capacity to act grants the person authority to enter into, alter and terminate legal relations. ${ }^{61}$

The Committee further differentiated legal capacity from mental capacity. According to it, legal capacity, which underlies significant involvement in society, involves the aptitude to hold and exercise rights and duties. ${ }^{62}$ Conversely, mental capacity refers to the decisionmaking abilities of a person, which differ from person to person as a result of factors such as environmental and social factors. ${ }^{63}$ It further acknowledged that both concepts usually are conflated to the effect that impaired decision making due to the presence of disability results in the removal of a person's legal capacity. ${ }^{64}$ This is particularly true for adolescent girls with intellectual disabilities who particularly are assumed to lack decision-making skills because of their disability, particularly in terms of health care and this often is enough reason for their sterilisation without their knowledge or consent. It reiterated that

\footnotetext{
56 Art 12(4) CRPD.

57 Frohmader (n 33 above) 71.

58 CRPD Committee 'Article 12: Equal recognition before the law' General Comment 1 (2014) CRPD/C/GC/1 para 1, http://daccess-dds-ny.un.org/doc/UNDOC/GEN/ G14/031/20/PDF/G1403120.pdf?OpenElement (accessed 8 October 2016).

59 Para 8 CRPD (n 58 above) para 8.

60 As above.

61 Para 12 CRPD Committee.

62 Para 13 CRPD Committee.

63 As above.

64 Para 15 CRPD Committee.
} 
article 12 does not allow the denial of legal capacity on grounds of a person having a disability or the existence of impairment but, rather, entails the provision of support in the exercise of legal capacity. ${ }^{65}$ Indeed, in a recent survey in Nigeria it was recommended that support be provided to persons with disabilities to suitably prepare and empower them to be autonomous citizens who make their own choices. ${ }^{66}$ So, such support in turn must have regard for 'the rights, will and preferences' of the person and never give rise to decision making by third parties. ${ }^{67}$ This challenges the traditional approach of denying legal capacity and vesting it in third parties on account of the presence of a disability (status approach), the effect of a person's decision (outcome approach) or perceived deficiencies in decisionmaking skills (functional approach). ${ }^{68}$

Article 12 also does not specify what form such support should take, but the CRPD Committee states that 'support' is a broad term that comprises informal and formal support measures, of different types and degrees. ${ }^{69}$ To Quinn, support entails 'capacity building' regarding 'social capital/community, widening opportunity to share

65 Paras 9 \& 15 CRPD Committee.

66 Federal Ministry of Women Affairs and Social Development 'Report of the National Baseline Survey on Persons with Disabilities (PWDs) in Nigeria' (2011) http:// www.womenaffairs.gov.ng/index.php/news-updates/169-report-of-the-nationalbaseline-survey-on-persons-with-disabilities-pwds-in-nigeria (accessed 8 October 2016).

67 Para 17 CRPD Committee.

68 Para 15 CRPD Committee. For detailed discussions on traditional approaches to legal capacity, see A Dhanda 'Legal capacity in the Disability Rights Convention: Stranglehold of the past or lodestar for the future?' (2006-2007) 34 Syracuse Journal of International Law and Commerce 429 431; B Collier et al Mental capacity: Powers of attorney and advance health directives (2005) 62-63; G Quinn 'Personhood and legal capacity perspectives on the paradigm shift of article 12 CRPD' presented at Harvard Law School Project on Disability (HPOD) Conference on Disability and Legal Capacity under the CRPD, Harvard Law School, 20 February 2010, http://www.nuigalway.ie/cdlp/documents/publications/ Har vard\%20Legal\%20Capacity\%20gq\%20draft\%202.doc (accessed 8 October 2016); E Flynn \& A Arstein-Kerslake 'Equal recognition before the law: Exploring a support model of legal capacity' paper presented at the Kent Critical Law Society Conference on 10 March 2012 at the University of Kent, Canterbury 5 http:// www.nuigalway.ie/disability-rights/downloads/kent_presentation.docx (accessed 8 October 2016); E Flynn \& A Arstein-Kerslake 'The support model of legal capacity: Fact, fiction, or fantasy?' (2014) 32 Berkeley Journal of International Law 124 129; Gibson (n 58 above) 232; D Gibson 'Conceptual and ethical problems in the Mental Capacity Act 2005: An interrogation of the assessment process' (2015) 4 Laws 229 231; K Purser Capacity assessment and the law: Problems and solutions (2017) 67; Centre for Disability Law and Policy NUI Galway 'Submission on legal capacity: The Oireachtas Committee on Justice, Defence and Equality' http:// www.nuigalway.ie/cdlp/documents/cdlp_submission_on_legal_capacity_the_oirea chtas_committee_on_justice_defence_and_equality_.pdf (accessed 8 October 2016); Council of Europe Commissioner for Human Rights 'Who gets to decide? Right to legal capacity for persons with intellectual and psychosocial disabilities' 19 https://www.coe.int/16806da5c0 (accessed 8 October 2016). 
personhood and grow as well as support in making decisions' ${ }^{70}$ It includes measures relating to universal design and accessibility. ${ }^{71}$ It could also constitute various, alternative means of communication, especially for persons who cannot verbally express their 'will and preferences' ${ }^{72}$ So, the nature and extent of support to be provided will differ considerably from person to person because of the diversity of persons with disabilities. ${ }^{73}$ Interestingly, the American Association on Intellectual and Developmental Disabilities (AAIDD), in its recent revised manual, was guided by the ideology of the CRPD and the social model of disability in classifying intellectual disability by levels of support rather than the level of severity. ${ }^{74}$ As Hatton points out, the AAIDD's reliance on support is important because, while a person may be capable of functioning well in a supportive environment, the same person may have difficulties in a less supportive environment. ${ }^{75}$ It could be argued that the right to 'support in the exercise of legal capacity' recognises that humans are inherently relational. As such, decision making and legal capacity should not be denied a person because human beings, disabled or non-disabled, are essentially relational and rely on the input of their families and friends in decision making. ${ }^{76}$ As Nedesky points out, individuals are structured by networks of relationships and usually are dependent on others and on the webs of relations of which they are part. ${ }^{77}$ According to her, Human beings are constituted by their relationships such that those relationships define the means through which their capacities are fostered, their rights are protected and their well-being is promoted. ${ }^{78}$ Hence, such relationships may be used to enhance the abilities of girls with intellectual disabilities by providing them with support in decision making, to protect them from involuntary sterilisation and guarantee their well-being.

With specific reference to children with disabilities (which includes adolescents with disabilities), the CRPD Committee also acknowledges that the right to legal capacity applies to them. ${ }^{79}$ According to the

70 G Quinn 'Some reflections on legal capacity: Is article 12 CRPD an evolution or a revolution?' http://www.mc.rs/upload/documents/saopstenja_izvestaji/2011/2810 11-MDRI-Gerard_Quinn.ppt (accessed 8 October 2016).

71 Para 17 CRPD Committee.

72 As above.

73 Para 18 CRPD Committee.

74 R Schalock et al Intellectual disability: Definition, classification, and systems of support (2010) 5.

75 C Hatton 'Intellectual disabilities - Classification, epidemiology and causes' in $\mathrm{E}$ Emerson et al (eds) Clinical psychology and people with intellectual disabilities (2012) 3 6-7.

76 AL Pearl 'Article 12 of the United Nations Convention on the Rights of Persons with Disabilities and the legal capacity of disabled people: The way forward?' (2013) 1 Leeds Journal of Law and Criminology 18.

77 J Nedelsky Law's relations - A relational theory of self, autonomy and law (2011) 20-28.

78 Nedelsky (n 77 above) 121.

79 Para 36 CRPD Committee. 
Committee, article 12 safeguards the 'equality of all persons before the law, irrespective of their age'. ${ }^{80}$ It also states that article 12 must be read together with article 7 which provides for the 'evolving capacities of children' and that 'due weight' is accorded their views in line with their age and development. ${ }^{81}$ However, the Committee, in adopting article 7 as the criterion for children with disabilities, adopts the functional approach to legal capacity which it condemns for adults with disabilities because it attempts to assess decision-making capacity. ${ }^{82}$ Moreover, the assessment of 'due weight' is left to the discernment of the person evaluating the legal capacity of a child in a particular context. ${ }^{83}$ However, it could be argued that the Committee's rationale for adopting the functional approach for children with disabilities could be to maintain the same standards as contained in the Convention on the Rights of the Child (CRC). ${ }^{84}$

Consequently, the legal capacity regime for adolescent girls with intellectual disabilities will differ from that of adult persons. According to Minkowitz, there is a need for the development of a system of legal capacity and support for children. ${ }^{85}$ Similarly, the Partnership to Ensure Reform of Supports in Other Nations (PERSON) was of the view that, although applicable to all persons, legal capacity may require some modification in the context of children. ${ }^{86}$ Thus, legal capacity for adolescents with disabilities, as garnered from the CRC and CRPD Committee, is tied to their understanding of the decision to be made, their age and to the rights accorded to their non-disabled counterparts. This functional approach, albeit with its shortcomings, is useful, as the presence of intellectual disability does not automatically entail a lack capacity for adolescent girls with intellectual disabilities. In fact, research shows that with age-appropriate support, adolescents with mild and moderate intellectual disabilities can consent to medical treatment. ${ }^{87}$ Indeed, Bogden and Levison have highlighted that a perceived disability is no reason to disregard a child's view or validate substituted decision-making by parents, guardians, carers or public

80 As above.

81 As above.

82 Para 15 CRPD Committee.

83 A Broderick 'Article 7 [Children with Disabilities]' in Della Fina et al (n 30 above) 195209.

84 Art 7 of the CRPD is equivalent to art 12 of the CRC. See United Nations Convention on the Rights of the Child (CRC) (1989) 28 ILM 1448, art 12.

$85 \mathrm{~T}$ Minkowitz 'CRPD article 12 and the alternative to functional capacity: Preliminary thoughts towards transformation' http://papers.ssrn.com/sol3/ papers.cfm?abstract_id=2371939 (accessed 8 October 2016).

86 Partnership to Ensure Reform of Supports in Other Nations (PERSON) 'Principles for legal capacity reform' Preamble http://www.eu-person.com/publication/ person-principles-english/wppa_open/ (accessed 8 October 2016).

87 JM Rey \& B Birmaher Treating child and adolescent depression (2007) 314. 
authorities. $^{88}$ They also stress that in keeping with their evolving capacities, children with disabilities, like other children, have valid insights into their wellbeing. ${ }^{89}$ Similarly, the United Nations Children's Fund (UNICEF) Report on the State of the World's Children recommends the inclusion of children (adolescents) with disabilities in decisions that affect them. ${ }^{90}$ Thus, the non-inclusion of adolescent girls with intellectual disabilities in decision making that affects their reproduction or discriminatorily sterilising them amounts to inequality and violates article 12.

\section{Challenges in the protection of adolescent girls with intellectual disabilities from involuntary sterilisation}

Negative stereotypes and beliefs are factors that cause girls with intellectual disabilities to be involuntarily sterilised. An example of such beliefs is that intellectual disability has spiritual and/or religious inferences, and that it is hereditary. ${ }^{91}$ So also are the assumptions that women and girls with intellectual disabilities are 'child-like', 'asexual', 'hyper-sexual', 'dependent', 'incompetent' and helpless. ${ }^{92}$ It is also widely believed that persons with intellectual disabilities are incapable of parenthood and have the potential to harm their children. ${ }^{93}$ Although these beliefs and stereotypes are unfounded, they are discriminatory as they are used to justify the sterilisation of women and girls with intellectual disabilities on an unequal basis with other adolescents.

The inability of parents and family members to provide financially for their intellectually-disabled children or their offspring is another challenge to protecting adolescent girls with intellectual disabilities from involuntary sterilisation. ${ }^{94}$ Empirical research shows that financial incapacity is acknowledged by parents as a reason to sterilise girls with intellectual disabilities in Nigeria. ${ }^{95}$ The provision of care and

88 J Boyden \& D Levison 'Children as economic and social actors in the development process' (2000) Working Paper 1, Expert Group on Development issues, Stockholm http://citeseerx.ist.psu.edu/viewdoc/download?doi=10.1.1.120.1198\& rep=rep 1 \& type =pdf (accessed 8 October 2016).

89 Boyden \& Levison (n 88 above).

90 UNICEF 'The state of the world's children 2013: Children with disabilities' Executive Summary, key recommendations, para $8 \mathrm{http}: / /$ www.unicef.org/ publications/files/SOWC2013_Exec_Summary_ENG_Lo_Res_24_Apr_2013.pdf (accessed 8 October 2016).

91 G Llewellyn 'The involuntary or coerced sterilisation of people with disabilities in Australia' https://sydney.edu.au/health-sciences/cdrp/Sterilisation_Submission\% 2021.pdf (accessed 8 October 2016).

92 Frohmader (n 33 above) 43.

93 As above.

94 L Dowse 'Moving forward or losing ground? The sterilisation of women and girls with disabilities in Australia' http://wwda.org.au/issues/sterilise/sterilise2001/ steril3/ (accessed 8 October 2016); Frohmader (n 33 above) 38-42. n 18 above. 
support for adolescents with intellectual disabilities usually is done by parents and/or family members and such care may be extremely onerous and financially tasking. ${ }^{96}$ This problem is further aggravated by the lack of social welfare and support systems for parents and family members, the unavailability and inaccessibility of reproductive health services and the economic dependence of adolescents with disabilities on their families. As such, families regard sterilisation as the only available option. ${ }^{97}$

Although the provisions of article 12 are laudable particularly in relation to addressing involuntary sterilisation, there is growing criticism arising from the CRPD Committee's conceptualisation of legal capacity and support in the exercise of legal capacity. One criticism is that article 12 may actually facilitate the violation of the rights of persons with intellectual disabilities, including adolescent girls with intellectual disabilities. The reality is that while adolescents with mild and moderate intellectual disabilities may be able to make decisions, including medical decisions, for themselves with support, those with severe and profound disabilities may not be able to do so. The presumption as proposed by the CRPD Committee ${ }^{98}$ that their will and preferences or the best interpretation of their will and preferences may always be discernible could result in substituted decision making which the CRPD sought to address. This is especially applicable to those with no support network, such as those in institutions, or those who cannot communicate their will and preferences, especially where assistive devices are lacking as in the case of developing countries like Nigeria. ${ }^{99}$ Tobin and Luke are of the view that in such cases substituted decision making is inevitable, irrespective of the support accorded to them, or allowance provided for their capacities to evolve. ${ }^{100}$ Quinn also acknowledges that that there may be instances where substituted decision making would be employed with respect to people whose will and preferences are imperceptible. ${ }^{101}$ Another concern is about the manipulation or inordinate control of adolescents with disabilities by the persons

96 K Del Villar 'Should supported decision-making replace substituted decisionmaking? The Convention on the Rights of Persons with Disabilities and coercive treatment under Queensland's Mental Health Act 2000' (2015) 4 Laws 173192.

97 Frohmader (n 33 above) 42.

98 Paras 20 \& 21 CRPD Committee.

99 OF Akinpelu et al 'Perspectives from the drafting of the UN Convention on the Rights of Persons with Disabilities' Discussion Paper for Side Event at UN Openended Working Group on Ageing 3-4.

100 J Tobin \& E Luke 'The involuntary, non-therapeutic sterilisation of women and girls with an intellectual disability - Can it ever be justified?' (2013) 3 Victoria University Law and Justice Journal 2737.

101 G Quinn 'Personhood and legal capacity: Perspectives on the paradigm shift of article 12' (2010) 13 http://www.nuigalway.ie/cdlp/documents/cdlp_submission _on_legal_capacity_the_oireachtas_committee_on_justice_defence_and_equality_. pdf (accessed 8 October 2016). 
meant to support them, especially in medical decision-making. ${ }^{102}$ The possibility of persons with disabilities deferring to their supporter altogether is also a challenge as it could result in the will of the person being supported not being reflected in the ensuing decision. ${ }^{103}$ Therefore, there is potential for support in decisions amounting to substituted decision making, especially for those with severe and profound intellectual disabilities who are vulnerable to the influence of others, thereby defeating the purpose of article 12.104 In such situations, it may be difficult to determine whether a supported decision is not a substitute decision. ${ }^{105}$ Therefore, the challenge is how to develop a model of support for adolescents with intellectual disabilities which does not result in paternalism even for those who can make decisions for themselves.

\section{Way forward}

Guaranteeing the effective implementation of the provisions of the CRPD is challenging, especially in the context of a developing country like Nigeria. Government plays a critical role in ensuring that human rights standards are implemented. It is their duty to promote, protect and fulfil human rights. In order to do this, the government must enact new laws or amend existing laws in Nigeria along the lines of the CRPD. As Dinnerstein pointed out, the enactment of laws will not automatically transform extant regimes 'but they are a start'. ${ }^{106}$ Thus, the government must enact laws to prohibit the sterilisation of adolescent girls with intellectual disabilities to ensure their right to equality and non-discrimination in line with the provisions of the CRPD. Anti-discrimination legislation is also crucial to protecting and promoting the rights of these girls, especially their right not to be discriminated against in retaining their fertility. Such law must also provide for the right to reasonable accommodation to aid them in making contraceptive decisions and prevent them from being sterilised. Such laws must prohibit the sterilisation of adolescent girls with intellectual disabilities. It must also guarantee the right of adolescents with intellectual disabilities to support in the exercise of legal capacity, especially in the context of decision making. If such support is provided by law, it goes a long way in mitigating the

102 P Gooding 'Navigating the "flashing amber lights" of the right to legal capacity in the United Nations Convention on the Rights of Persons With Disabilities: Responding to major concerns' (2015) 15 Human Rights Law Review 45 58-60.

103 Gooding (n 102 above) 58-60.

104 The Cambridge Intellectual and Developmental Disabilities Research Group 'Submission to the Committee on the Rights of Persons with Disabilities' 2 http:// www.psychiatry.cam.ac.uk/ciddrg/files/2014/02/Article-12-CRPD-12-07-11.pdf (accessed 8 October 2016).

105 As above.

$106 R D$ Dinerstein Implementing legal capacity under article 12 of the UN Convention on the Rights of Persons with Disabilities: The difficult road from guardianship to supported decision-making' (2012) 19 Human Rights Brief 12. 
involuntary sterilisation of girls with intellectual disabilities. The government must also not to permit substitute decision-makers to provide consent to sterilisation on behalf of girls with disabilities. All health and medical personnel should ensure that third parties, including family members, do not make decisions about the sterilisation of the girls. The government must take steps to prevent the infringement of the right by non-state actors. ${ }^{107}$ In developing a supported decision-making regime, it must ensure that other rights such as the right to autonomy, informed consent, to retain fertility and human dignity are protected and ensure that the support provided is not used as a justification for limiting their rights. ${ }^{108}$

Although supporting adolescent girls with intellectual disabilities, especially where they cannot make decisions, may be challenging, an approach that still promotes their human rights, especially their rights to retain their fertility, equality and non-discrimination are required. Perhaps an approach that recognises that the child is situated within a network of relations and that shares the decision making between the child and the network is required. This could consist of 'support networks' consisting of a 'small group of individuals' that have a personal relationship and are well acquainted to the girl, such as family members, and friends, undertaking to assist her in making decisions. ${ }^{109}$ Thus, in as much as the child may not be able to make decisions, there are people who love and understand the child and who can enable or facilitate decisions on behalf of the child in a way that fosters the child's right to support. This relational conceptualisation of legal capacity allows us to appreciate children with severe and profound disabilities as both individuals with rights to be protected and as dependent on others for care. ${ }^{110}$ Such an approach also emphasises the importance of providing support for the child and fostering relationships between those involved in caring for the child and the child. ${ }^{111}$ According to Bridgeman, it requires 'an understanding of the child as both an individual and as situated within a web of relationships such that the insights, knowledge and experiences of parents' and others involved in the child's life are important. ${ }^{112}$ It would ensure that girls with intellectual disabilities are not subjected to involuntary sterilisation.

The support networks require a legal and policy framework, capacity building and provision of infrastructure as well as 'a

107 Para 24 CRPD Committee.

108 Para 29 CRPD Committee.

109 M Bach 'Supported decision making under article 12 UN Convention on the Rights of Persons With Disabilities: Questions and challenges' presented at the Conference on Legal Capacity and Supported Decision Making at Athlone, 3 November 200711.

110 J Bridgeman 'Caring for children with severe disabilities: Boundaried and relational rights' in M Freeman (ed) Children's health and children's rights (2006) 99113.

111 Bridgeman (n 110 above) 113.

112 Bridgeman 116. 
registration process for designated supporters' to be regarded as legitimate. ${ }^{113}$ There are, however, some instances where the support network may not be feasible such as where the girls are institutionalised and lack 'familial relationships' and as such may result in substituted decision making may be inevitable. ${ }^{114}$ Nonetheless, substitute decision making in the context of sterilisation of adolescents with severe and disabilities should never be considered as a means of assisting the adolescent.

There also is a need for awareness-raising programmes in society to promote the rights and dignity of persons with disabilities, to stimulate positive outlooks about them and to tackle stereotypes, preconceptions and harmful traditions involving them. ${ }^{115}$ Such programmes should be directed at families, communities, grassroots and urban alike, policy makers, law enforcement agencies and stakeholders, including adolescents with intellectual disabilities and their advocacy groups. It entails collaboration between different sectors, including government and governmental agencies, nongovernmental organisations (NGOs), community leaders, medical professionals and the media. ${ }^{116}$ This would promote a constructive image of persons with disabilities as part of human diversity with diverse abilities and personalities. An example of a multi-personal awareness-raising strategy is walks and road shows as have been organised in Nigeria by the Down Syndrome Foundation Nigeria, Children's Developmental Centre and Mo Rainbow Foundation. ${ }^{11}$ Other awareness-raising strategies include celebrating designated days, such as Down Syndrome Day, public presentations, workshops, seminars, fund-raising events, musical and theatrical shows, campaigns and media reports. Training programmes for policy makers and relevant stakeholders, including adolescent girls with intellectual disabilities themselves, governmental officials, health care personnel,

113 Bach (n 109 above) 13-14.

114 Tobin \& Luke (n 100 above) 37; Gooding (n 99 above) 58-60.

115 Art 8 CRPD.

116 I Worm A human rights-based approach to disability in development: Entry points for development organisations (2012) 26; K Scior et al 'Intellectual disabilities: Raising awareness and combating stigma - A global review' (2015) 84 https:// www.ucl.ac.uk/ciddr/documents/Global_ID_Stigma_Report_Final_July_15.pdf (accessed 8 October 2016).

117 D Sadiq 'Walkabout for Down syndrome' https://worlddownsyndromeday.org/ wakabout-down-syndrome-nigeria (accessed 8 October 2016); C Obinna 'Walk with us, save 12 babies' http://www.vanguardngr.com/2015/03/walk-with-ussave-12-babies/ (accessed 8 October 2016); 'Down Syndrome Foundation focuses on awareness' http://www.vanguardngr.com/2014/10/ syndrome-foundationfocuses-awareness/ (accessed 8 October 2016); 'Down Syndrome Foundation Nigeria holds awareness week' http://www.transparentnigeria.com/news_entries/ 8228/Down-Syndrome-Foundation-Nigeria-Holds-Awareness-Week (accessed 8 October 2016); Scior (n 116 above) 84; E ljewere-Kalejaiye 'I will do my best and give hope to children living with Down syndrome' https://guardian.ng/ guardian-woman/i-will-do-my-best-and-give-hope-to-children-living-with-downsyndrome/ (accessed 8 October 2016). 
teachers and other providers of services on the rights of persons with disabilities, are also of the essence. ${ }^{118}$

Civil societies similarly are crucial in ensuring the enforcement of human rights; holding governments accountable for the nonpromotion of rights; challenging existing discriminatory norms; and facilitating the implementation of revolutionary norms and standards. ${ }^{119}$ Article 33 requires state parties to establish implementation and monitoring mechanisms at the domestic level, with the participation of civil society, including persons with disabilities and their representative organisations. ${ }^{-20}$ This would enable civil societies and disabled persons' organisations (DPOs) in Nigeria to keep watch on the government's compliance with the CRPD and in turn report to the CRPD Committee in line with article 33. Civil societies and DPOs, therefore, could be catalytic in ensuring that adolescent girls with intellectual disabilities are not sterilised without their knowledge or consent and promoting their rights.

\section{Conclusion}

The article has sought to learn from the provisions of the CRPD with regard to protecting adolescent girls with intellectual disabilities from involuntary sterilisation. It emphasises the importance of the provisions of the CRPD in ensuring that adolescent girls with intellectual disabilities are protected from the inequality and discrimination characterised by involuntary sterilisation. The article shows that involuntary sterilisation is discriminatory and involves the unequal treatment of adolescent girls with intellectual disabilities. It also shows that the involuntary sterilisation of the girls is reified by socio-economic, cultural and even legal factors. The shortcomings of extant laws in Nigeria and the lack of commitment on the part of the Nigerian government in promoting and protecting girls from involuntary sterilisation also are highlighted. It was also emphasised that the rights to respect for the home and family, equality and nondiscrimination, equal recognition before the law and health contained distinct provisions that are useful in protecting adolescent girls with intellectual disabilities from involuntary sterilisation. Measures such as the enactment and revision of laws, awareness raising and NGO action were recommended. It is therefore hoped that legislators and policy makers resort to the provisions of the CRPD when enacting laws or designing policies and programmes and apply them in the Nigerian

118 Dinnerstein (n 106 above) 12.

119 As above; 'Civil society provides the critical foundation for promoting all human rights' https://geneva.usmission.gov/2011/09/15/civil-society-promoting-allhuman-rights/ (accessed 8 October 2016); Kingdom of Morocco National Human Rights Council 'Promotion and protection of human rights: Role of civil society' http://www.cndh.org.ma/an/bulletin-d-information/promotion-and-protectionhuman-rights-role-civil-society (accessed 8 October 2016).

120 Arts 33(1) \& 33(3) CRPD. 
context. Undoubtedly, implementing some of the provisions of the CRPD in Nigeria may be challenging, but the benefits outweigh the challenges as they would prevent the unequal treatment and discrimination against adolescent girls with intellectual disabilities. 